Marilyn P. Safir ${ }^{1}$

'University of Haifa, Haifa, Israel

\title{
How It All Began: Women's Worlds Congress and International Network
}

Abstract: Presented by the founder and Chair of the First Women's Worlds, held in Israel in 198182 , this article historicizes the development of this international interdisciplinary congress up to its $13^{\text {th }}$ edition in Brazil. It also discusses the creation of the Worldwide Organization of Women's Studies (WOWS) and the close relationship it bears with the pre- and post-conference coordination. Keywords: Women's Worlds; WOWS (Worldwide Organization of Women's Studies)

The First International Interdisciplinary Congress on Women: Women's Worlds: The New Scholarship was held at the University of Haifa in Israel on December 27, 1981 - January 1, 1982. I was the founder and Chair and my Co-Chairs/founders were Martha Mednick (Howard University) and Dafna Izraeli (Tel Aviv University).

I had arrived in Israel in 1968 with a new Ph.D. in psychology and the expectation to work in a modern egalitarian society that had dealt with the "woman question" during the '20's. It quickly became clear that the status of women in Israel was less advanced than in the U.S. In order to develop awareness of the inequality within Israeli society, Marcia Freedman (who was latter elected to the Knesset on Shulamit Aloni's Citizen's Rights Party) and I began two consciousness raising (CR) groups in 1970, at the University of Haifa. Women from these two groups joined forces to establish a new Women's Liberation movement. We began to attract media attention. As a result, Martha Mednick, on sabbatical in Israel in 1972, to study kibbutz women, read about the group and initiated a meeting. She told us about the new feminist scholarship taking hold in the U.S. Mednick planted the idea of Women's Studies in fertile ground.

When I started to receive requests from Israeli colleagues in other fields about existing feminist research in psychology, it became obvious that interdisciplinary communication was lacking. I discovered that feminist scholars worked in isolation and were unaware of each other's work, because of the absence of a national network. Women's Studies was nonexistent

\section{(c) (7)}

Esta obra está sob licença Creative Commons. 
and unknown in Israeli academia. We were also at a disadvantage in keeping up with the latest research findings. Twenty years ago, mail between Israeli cities took 10 days to 2 weeks and international mail a month, at best. Journals could take 3-4 months to arrive from abroad - if they arrived at all. World-wide, there were no computer networks or data bases - no online data. You had to search through printed abstracts for each related profession.

In discussions with Mednick, it became obvious that lack of interdisciplinary communication was a problem in the U.S. as well. We continually discussed the need for an international, interdisciplinary congress that focused on scholarship on women. Finally, in 1979, we decided to do something about it. We proposed holding such a congress under the auspices of the American Psychological Association's Division 35 - Psychology of Women Council. We also proposed holding this Congress in Israel in order to make Israeli universities aware of and to create the ground work to establish WS programs. The Congress seemed to be a way to bring the message of the importance and developing stature of the new scholarship to this isolated place, as well as to create both Israeli and international networks.

Division 35 agreed to be a co-sponsor - but could only offer enthusiastic support and the mailing lists of the organization. Since no budget was available, it was stressed that we had to find other organizations to co-sponsor the congress. We were fortunate, because among the executive committee members were Florence Denmark, President-Elect of APA, and Nancy Felipe Russo, who was the President of the Federation of Organizations of Professional Women (FOPW), composed of 110 organizations with branches all over the world. Nancy proposed that the Federation become a Co-sponsor. Jessie Bernard and Dafna Izraeli invited Sociologists for Women in Society (SWS) to be another co-sponsor.

When we discussed names for the Congress, it was obvious to all of us that the "New Scholarship" would be the code word for feminist scholarship. Martha suggested that we use "Women's Worlds" in honor of Jessie Bernard's newest book that was about to be published. (Jessie joined the International Organizing Committee and agreed to be a keynote speaker). I asked the feminist scholars I knew to join the Israeli board and scientific committee. I also requested they ask their respective five universities to become co-sponsors. Only the University of Haifa - my home base - agreed to sponsor the Congress and, more importantly, to host the meetings on its campus. However, Dafna Izraeli, who was at that time at Tel Aviv University, joined me as Israeli Co-chair.

It is difficult to imagine the hardships of communication, both nationally and internationally in 1979, because poor postal service was something to contend with on a daily basis. To telephone internationally, you had to reach an operator and place the call often waiting 2-3 hours for the call to go through. No direct dialing - no faxes or Internet. This was the framework from which we had to work both in planning the Congress and then in communicating with potential participants. When we received no response, we had to assume it might be that the person never received our correspondence. Many letters were sent two or three times.

An International Organizing Committee (with major fundraising activities in New York City and Washington, D.C.) was formed and Mariam Chamberlain, of the Ford Foundation, granted seed money that enabled us to 'get the ball rolling.' The National Science Foundation awarded $\$ 25,000$ to be used for travel funds for young scholars. As powerful women joined the International Organizing Committee, they helped the organizing process by soliciting a large group of organizational co-sponsors. The Division of the Psychology of Women, Sociologists for Women in Society (SWS), and the Federation of Organizations of Professional Women (FOPW) took the lead. FOPW in particular provided a home and served as a funding conduit. Many of FOPW's organizations were very active in publishing information about the Congress in their newsletters. 
Open calls for papers appeared in professional and interdisciplinary journals throughout the world. Over 2000 inquiries were received, and over 400 abstracts were submitted to the Program. There were a total of 90 sessions at which 258 papers were presented; 623 participants from 36 countries attended. The Congress Directory of participants, along with the names and addresses of all people who corresponded with us, formed the basis for the new international network. In fact, the letters and envelopes were packed in a suitcase and hand delivered to Christine Classon in the Netherlands, where the second Congress was held.

The first Congress was unique in a number of ways. Historically, it was the first worldwide interdisciplinary congress to focus on research on wom en and to be open to all interested researchers and grass roots activists. There was no one organization sponsoring and running the meetings. It was, rather, an informal collection of individuals and professional organizations, joined together for the sole purpose of organizing the event. It was a feminist congress, not only in its scholarship but also in its very conception and development. The Program Committee agreed at the outset to hold a non-elitist conference so as to reach the widest range of potential participants. We looked at the congress as a socializing experience for aspiring and up-and-coming researchers. Consequently, no abstract was rejected outright. Whenever the criteria for acceptance were not met, reviewers asked for improvement or clarification, with an option to resubmit. The committee was rewarded for its efforts. In the majority of cases, the abstracts were resubmitted and integrated into the program. This extra effort had the effect of allowing many students and young scholars to participate. An attempt was also made to keep every session interdisciplinary and international.

Several specific international networks (i.e. Women in Management) were established as offshoots of the international network that was created. Another first was inviting grass roots groups to present their projects in Poster Sessions to enable them and academics to network during these sessions. While causing some difficulties to the organizers, registration fees were charged on a sliding scale to enable participants from the developing world, students and grass roots volunteers to attend. To enable participation of community women and people of limited funds, Haifa residents provided free lodging in their homes to many participants who could not afford to pay hotel fees. Tours were offered to all the grass-roots projects in and around Haifa for interested participants. Many Haifa residents invited participants to their homes for a social evening, as well.

The First Congress had an international impact. There were glowing news articles on the front page of the New York Times, in Time Magazine and in newspapers in most of the participants' home countries. We were sent articles in Japanese, Greek, French, Spanish, from Latin America, from Africa, etc. This increased the impact in Israel. The Israeli media was flooded with reports, interviews, and photos. The Congress had specific impact on the development of feminist scholarship in Israel. In 1982, Hebrew University started a program on Sex Differences in Society. In 1983, the University of Haifa inaugurated the first Women's Studies program and, in 1984, Project Kidma for the Advancement of Women - an outreach program originally for community women. In 1984, the Israel Sociological Association also established a section on Sex and Gender.

\section{Creating Future Congresses}

On the final day, Matti Kubrick Gershenfeld called a general meeting to evaluate the Congress and to discuss the future. Over 100 people attended. All enthusiastically agreed that this should be "The First" in a series of congresses. Some suggested that an international organization be formed to take responsibility for and sponsorship of continuation of the 
Congress. However, the general feeling was that to maintain the momentum created in this First Congress, another university should take responsibility for organizing the next Congress. Donna Shalala, at that time President of Hunter College, immediately offered Hunter College's facilities. However, there was general agreement that it was too soon to take the Congress to the U.S. if we wanted to continue to encourage and develop the international flavor. It was agreed to hold the Congress only in countries that would give visas to all participants worldwide. A call for bids went out through channels of information that were established for the 1st Congress. The University of Haifa served as the secretariat. Four bids were received; the University of Groningen, in the Netherlands, was chosen by a committee composed of the Congress Chair, Co-chairs and Congress board from several countries. The $2^{\text {nd }}$ Congress Chair, Christine Classon, and Co-Chair, Helen Hootsman, received the suitcase filled with the directories and almost 3000 letters and envelops with correspondents addresses. This Congress theme was Strategies and Empowerment. Close to 800 participants attended. The participants filled all the city's hotels and some had to be housed up to 25 Kilometers from Groningen and had to commute by train. As there had been Irish involvement in organizing the first Congress, there was interest in holding a Congress in Dublin. Trinity College made the bid that was accepted for the third Congress in 1987. This Congress was organized by a collective: Mary Cullen, Audrey Dickson, Margaret Fine-Davis, Sylvia Meehan, and Geraldine Maone. Its theme was Visions and Revisions. The number of attendees jumped. The organizers were able to attract approximately 2,000 grassroots participants and about 1,400 academics. The $3^{\text {rd }}$ Congress took over Dublin during this period. Hunter College in New York City became the $4^{\text {th }}$ Congress' venue in 1990 with its theme: Realities and Choice. It was chaired by Florence Denmark and Susan Lees. This was a huge Congress with similar number of participants to the Dublin Congress. However, N. Y. City swallowed the Congress and there was much less impact in and on the City itself. From there, the $5^{\text {th }}$ Congress went to the University of Costa Rica in San Jose, where it was chaired by Mirta Gonzalez-Saurez in 1993: this theme was Search, Participation, Change. There were over 1,000 participants with a large contingent from South and Central America. The Congress and participants again had a strong impact on San Jose with daily coverage on TV and in the newspapers. The University of Adelaide, Australia, hosted the $6^{\text {th }}$ Congress in 1996 - Think Global, Act Local, which was Chaired by Susan Magarey, and was attended by over 1,000 participants $A$ major goal was to engage scholars from all over Asia. This goal was not fully realized. The $7^{\text {th }}$ Congress, whose theme was Genderations, was chaired by Gerd Bjorhovde at University of Tromsö in 1999 with 1,700 participants whose presence could be felt all over Tromsö. The Congress Committee was successful in bringing a large international contingent from the developing world, in part because they raised funds for travel grants. Grace Bantebya Kyomuhendo and her team from the Women and Gender Studies Department at Makerere University organized the $8^{\text {th }}$ Congress: Gendered Worlds: Gains and Challenges. Congress and participants again had a strong impact on the University and Kampala. The President of Uganda addressed the Congress opening the 1957 participants from 100 countries and every country in Africa. The $9^{\text {th }}$ Congress - Globalization from Women's Perspectives was held in Seoul, Korea in 2005 and was hosted by Ewha Women's University and the Korean Association of Women's Studies and Chaired by Pilwha Chang and Co-Chaired by Kim Eunshil of Ewha Woman's University, Son Seungyoung, of Dongduk University and the Korean Association of Women's Studies was General Secretary and Roh Jieun, representative of Secretariat. Up to this point this was the largest and most international of the WW congresses with spectacular social events do to funding from the local government with almost 3000 attendees from all over the world. The $10^{\text {th }}$ Congress, 2008 was held at the University of Madrid and chaired by Teresa Langle de Paz, with the Congress theme New Frontiers: Dares, 
Challenges and Changes. The Madrid Congress hosted 3,700 participants on a large metropolitan campus. As a result of the large number of participants in this very large campus, there had been less interaction among the participants. The $11^{\text {th }}$ congress was held at the University of Ottawa, Co-chaired by Caroline Andrew and Rianne Mahon and entitled Women's Worlds 2011 - Connect-Converse with Lise Martin as coordinator. In contrast with the Madrid congress that was very spread out, the Ottawa congress was very "intimate" taking over a contained campus and adjacent dormitories, enabling the participants to interact between sessions and following them. The $12^{\text {th }}$ Congress was held in Hyderabad University, India in 2014 and Chaired by Rekha Pande and Co-Chaired by Sita Vanka. The theme was Gender in a Changing World with over 1,000 participants. We finish this review at the $13^{\text {th }}$ Congress in CFH - Universidade Federal de Santa Catarina in Florianopolis, Brazil which is occurring concurrently with the $11^{\text {th }}$ Congress Doing Gender and Co-chaired by Cristina Scheibe Wolff and Miriam Grossi.

\section{Organization of Worldwide Organization of Women's Studies (WOWS)}

As previously mentioned, time and facilities at the first Congress were not suitable for the formation of an international organization to organize future Congresses. Marilyn Safir served as the Chair of the Secretariat at the University of Haifa, and the Organizers of the next few Congresses joined the Congresses organizing committee. However by 1985, time appeared appropriate for the concept and the development of a worldwide association of women's studies organizations. This concept was presented at the NGO Forum of the United Nations in 1985 in Kenya. Both Tobe LEVIN (1992) and Erna KAS (2002) raised the idea at different NGO meetings in Nairobi. At a breakfast meeting, Tobe Levin met with Jalna Hanmer, Maitreyi Krishna-Raj, Gloria Bonder, and Peggy Mclntosh. They discussed the importance of an international organization. However, a decision was made that the first step would be the formation of a European women's studies association, which would later become WISE (Women's International Studies Europe). A follow-up meeting in 1987 at the $3^{\text {rd }}$ Congress in Dublin gave further impetus to the establishment of WISE as did grants in 1988 and 1989 from the European Union. Because of EU funding, membership was originally limited to WS associations from member states. Judith EZEKIEL (2002) pushed for the inclusion of non-EU membership. She also suggested the name Worldwide Organization of Women's Studies (WOWS) and began lobbying for WOWS establishment at the Vienna preparatory conference for Beijing. At the NGO meetings in Beijing in 1995, WISE proposed the establishment of a world-wide organization. They were joined by the National Women's Studies Association of the USA. Judith Ezekiel and Erna Kas of WISE and Claire Moses of NWSA organized a series of workshops, and 165 women from 43 countries joined hands to endorse the creation of a worldwide organization of feminist/women's studies associations. WOWS was composed of one WS organization from each country and not individual members.

As the Beijing sessions were such smashing success, it was decided to have an official founding meeting at the $6^{\text {th }}$ International Interdisciplinary Congress on Women in Adelaide, and WOWS was officially launched at that Congress. The first General Assembly meeting of founding members was held in Tromsö at the $7^{\text {th }}$ Women's Worlds Congress. Now the time had come: rather than the organizers of the WW Congresses and the individual universities that served as hosts deciding on the venue for the following congress, WOWS formed a site-selection committee for the next conference. After the Congress, WOWS sent out a call for proposals to organize the next conference. Makarere University was chosen for the 2002 Congress site. 
Holding the next meeting in 2005 in Asia had priority, in part because few participants from Asia managed to attend earlier conferences - not even the meeting in Australia, where a large Asian presence was anticipated. Thus WOWS searched for an Asian site for the 9th Congress. Ewha Women's University and the Korean Association of Women's Studies were chosen to host Globalization from Women's Perspectives in Seoul, Korea, in 2005.

Claire MOSES (2017) has pointed out that WOWS past and present conference chairs and coordinators are so intertwined that it would be impossible to see them as two separate entities. For example, part of the responsibility of the conference university and congress chair and/or coordinator - post-conference - is to host the WOWS secretariat for the next 3 years. Also, the WOWS committee is responsible for the conference site selection of the next congress. This committee is composed of former congress coordinators - at least ideally. Unfortunately several former congress coordinators were unable to continue the secretariat, which resulted in former WOWS steering committee members taking over section of the new site. WOWS is the entity that connects the present, future, and past coordinators and is there for advice and backup. For example, people who had a longtime connection to WOWS are still called on to serve on the selection committee and to offer advice. Claire represented WOWS in pre-Congress planning here in Florianopolis. When Congress Coordinators were unable to follow in soliciting and finding potential Congress locations, we can thanks WOWS for ensuring the following congress sites were chosen ensuring continuity.

\section{References}

EZEKIEL, Judith. Personal Communication, 15/7/2002.

KAS, Erna. Personal Communication, 15/7/2002.

LEVIN, Tobe. "Women's Studies Networking in Europe: Introduction to the European Network for Women's Studies (ENWS) and Women's International Studies Europe (WISE)". Women's Studies Quarterly, v. 20, n. 3/4, New York: The Feminist Press at the City University of New York, 1992. p. 153-162.

MOSES, Claire. Personal Communication, 24/4/2017.

[Received on $24 / 08 / 2018$ and accepted on $31 / 08 / 2018$ ]

Como tudo começou: o congresso Mundos de Mulheres e a rede internacional Resumo: Apresentado pela fundadora e organizadora do primeiro Mundos de Mulheres, realizado em Israel em 1981-82, este artigo faz um histórico do desenvolvimento desse congresso internacional e interdisciplinar até sua mais recente $13^{a}$ edição, no Brasil. Também discute a criação da WOWS (Organização Mundial de Estudos sobre a Mulher) e a íntima relação entre esse grupo de pesquisadoras e a coordenação do Congresso.

Palavras-chave: Mundos de Mulheres; WOWS (Organização Mundial de Estudos sobre a Mulher)

Marilyn P. Safir (marilyn.safir@gmail.com) is Professor Emerita of Psychology and director of Project KIDMA, which she founded in 1983, for women's development ay University of Haifa, in Israel. She was also the founder and first president (1998-2002) of the Israeli Association of Feminist and Gender Studies (IAFGS) and the organizer of the first international congress of women's studies, the Women's Worlds, held in Haifa in 1981. She has received various prizes for her work, such as the "Florence Denmark and Gori Gunvald Award for Research on Women and Gender" of the International Council of Psychologists, in 2002.

iD 0000-0001-6079-6854

6 Revista Estudos Feministas, Florianópolis, 26(3): e58818 